\title{
A QUALITATIVE STUDY ON THE ROLE OF EXCLUSIVE BREASTFEEDING COUNSELOR AT MUHAMMADIYAH HOSPITAL, GRESIK, EAST JAVA
}

\author{
Siti Hamidah, Sri Rulihari \\ Academy of Midwivery Delima Persada, Gresik, East Java
}

\begin{abstract}
Background: Exclusive breastfeeding aims to ensure the fulfillment of the right of the infant for good nutrition needs. Breast milk contains antibodies and almost all the nutrients the baby needs. Exclusive ASI coverage in 2015 in Indonesia was 55.7\%, East Java 74.1\%, Gresik Regency 70.9\%. In 2016 exclusive ASI coverage declined, in Indonesia 29.5\%, East Java 48.1\%, and Gresik Regency 55.72\%. Conceptually, increasing the role of ASI counselors, family support, and women's organizations is an important part of efforts to increase exclusive breastfeeding coverage. This study aimed to assess the performance of exclusive breastfeeding counselors at Muhammadiyah hospital, Gresik and the formation of women's organizations (Aisyiyah) exclusive breastfeeding supporters in Gresik Regency.

Subjects and Method: This was a descriptive qualitative study. The study population was 600 breastfeeding counselors in Gresik Regency, East Java. The main informants were 2 breastfeeding counsellors at Muhammadiyah Hospital, Gresik (RSMG), East Java. The key informant included the head of the Hospital Training, head of the Nursing Department, and head of the Maternal and Child Health. Supporting informants included midwife coordinator of out-patients and in-patients. The data were collected by in-depth interview and focus group discussion. The study instrument was an interview guide. Data were analyzed by triangulation.

Results: Breastfeding counselors have done a good job program. The drawback was the lack of documentation. Monitoring of follow-up mothers and babies born in RSMG needs to be addressed. Aisyiyah breastfeeding group has been formally established in all branches of Gresik Regency.

Conclusion: Communication Information Education (KIE) needs to be done through online social media. A special monitoring and evaluation team needs to be established so that exclusive breastfeeding coverage can be properly monitored and followed up to increase coverage of exclusive breastfeeding mothers.
\end{abstract}

Keywords: exclusive breastfeeding, counselor

\section{Correspondence:}

Siti Hamidah. Academy of Midwivery Delima Persada, Gresik, East Java.

Email: sitihamidahtw24@gmail.com. Mobile: 081553520203. 